九州大学学術情報リポジトリ

Kyushu University Institutional Repository

\title{
Studies On Foodstuffs In Emergencies. XXII. On The Starch Of Lycoris Radiata
}

Yamafuji, Kazuo

Faculty of Agriculture, Kyusyu University

Tono, Tetsuzo

https://doi.org/10.5109/22640

出版情報：九州大学大学院農学研究院紀要. 9 (4)，pp. 355-360，1950-11. Kyushu University バージョン：

権利関係 : 
Journal of the Faculty of Agriculture, Kyūshū University, Vol. 9, No. 4

November 30,1950

\title{
STUDIES ON FOODSTUFFS IN EMERGENCIES. XXII. ON THE STARCH OF LYCORIS RADIATA
}

\author{
Kazuo Yamafuji and Tetsuzo Tono
}

Lycoris radiatt has been generally called "Higanbana' in Japan and its bulb contains a considerable amount of starch. This plant is widely distributed in various fields and forests, but it is unsuitable for eating. There exist several poisonous alkaloids in the bulb of Lycoris and the chemical constitution of lycorine, the principal base, was clarified by Kondo et al (1). Since these alkaloids have been utilized as medicine, we already studied the extraction, adsorption (2) and elusion (3) of the bases. On the other hand Kihara (4) investigated the nature of polysaccharides in Lycoris root, and in this institute we also performed some experiments concerning the alcoholic fermentation (5) of these polyoses. In the present article we shall report the results of investigations on the isolation of starch and its decomposition by amylase.

\section{EXPERIMENTAL}

1. Isolation of starch: The tubers of Higanbana were gathered, dried at room temperature and ground in a mortar. The analysis of this powder gave the data shown in Table 1.

Table 1. Chemical composition of root powder.

\begin{tabular}{c|c|c|c|c|c}
\hline Starch, \% & Reducing sugar, \% & Total N, \% & Fibre, \% & Ash, \% & Water, \% \\
\hline 48.65 & 1.63 & 0.61 & 2.82 & 3.26 & 18.07 \\
\hline
\end{tabular}

An example of isolation experiments was carried out as follows: $5 \mathrm{~g}$ bulb powder was mixed with $50 \mathrm{~g}$ water and after 20 hrs. supernatant liquid decanted. The residue was thoroughly 
ground in a glass mortar, filtered through a gauze and mixed with water again. This procedure was repeated 3 times and starch particles deposited were gathered. The yield of starch averaged $60 \%$.

It is assumed that the extraction of starch from tuber is influenced by the hydrogen ion concertration of solution. The tuber powder was immersed into diluted hydrochloric acid and in similar manner starch prepared. The results obtained are given in Table 2.

Table 2. Relatien between yield of starch and acidity of solution.

\begin{tabular}{c|c|c|c|c|c|c|c|c}
\hline Conc. of $\mathrm{HCl}, \%$ & 0 & 0.1 & 0.2 & 0.3 & 0.4 & 0.5 & 0.6 & 0.7 \\
\hline Yield of starch, \% & 45 & 60 & 77 & 88 & 81 & 75 & 65 & 60 \\
\hline
\end{tabular}

By hydrochloric acid of $0.2-0.5 \%$ some constituents other than starch are extracted from the plant material. Therefore, the preparations made by using such acid solutions were impure.

In order to compare the extracting power of alkalis with that of acids $100 \mathrm{cc}$ of solution was added to $1 \mathrm{~g}$ of bulb powder, after $20 \mathrm{hrs}$. at $36^{\circ} \mathrm{C}$ the mixture filtered and the sugar content in this filtrate determined after the hydrolysis.

Table 3. Extraction of starch by alkali.

\begin{tabular}{l|c|c|c|c|c|c}
\hline Conc. of reagent, $\%$ & $0.2 \% \mathrm{NaOH}$ & $0.2 \%$ & $\mathrm{Na}_{2} \mathrm{CO}_{3}$ & $\mathrm{H}_{2} \mathrm{O}$ & $0.2 \% \mathrm{H}_{2} \mathrm{SO}_{4}$ & $0.2 \% \mathrm{HCl}$ \\
\hline Yield of starch, $\%$ & 22.5 & 22.3 & 20.7 & 21.3 & 22.6 \\
\hline
\end{tabular}

It can be seen from the data in Table 3 that the amount of starch which was extracted by diluted alkalis is much the same as that obtained by treating with acids. Moreover, the alkaline solution of Lycoris root is glutinous and we are urrable to isolate from this a starch precipitate.

It appears to us that the yield of starch varies with the time of extraction. $5 \mathrm{~g}$ of root powder were immersed into $30 \mathrm{cc}$ of water and after $3 \mathrm{hrs}$. the mixture was filtered. The residue was ground with water and then it was left stand at $24^{\circ} \mathrm{C}$ for 1 to 8 days. From these solutions starch particles were gathered by the filtration with a cotton cloth. 
Table 4. Relation between time of extraction and yield of starch.

\begin{tabular}{l|c|c|c|c|c|c|c|c}
\hline Time of extraction, day & 1 & 2 & 3 & 4 & 5 & 6 & 7 & 8 \\
\hline Yield of starch, $\% \ldots . .$. & 40.9 & 48.3 & 53.8 & 56.9 & 57.2 & 51.6 & 47.5 & 45.5 \\
\hline
\end{tabular}

It will be seen from Table 4 that too short or too long extraction gives rather a low yield of tuber starch. Therefore, the time of immersion must be regulated according to the temperature.

The powder of Lycoris bulbs swells in water and this phenomenon seems to have a close connection with the extraction of starch. Accordingly, we selected the particles of the same size out of a large quantity of bulb powder, put them in a graduated tube which has been held in water and after varying time intervals determined the volume of swollen particles. The experiments of this kind resulted that after $1 \mathrm{hr}$. at $27^{\circ} \mathrm{C}$ the root powders swelled to $180 \%$ and after about 2 hrs. the degree of swelling reached to its maximum, namely $190 \%$.

The figures in Table 5 showed that the increase of particle volume after the immersion in water is affected by the variation of temperature.

Table 5. Variation of swelling by temperature.

\begin{tabular}{l|l|l|l|l|l|l|l|l|l|l}
\hline Temp. of inmersion, ${ }^{\circ} \mathrm{C}$ & 15 & 20 & 25 & 30 & 35 & 40 & 45 & 50 & 55 & 60 \\
\hline Degree of swelling, \% & 164 & 178 & 188 & 208 & 226 & 246 & 258 & 268 & 250 & 200 \\
\hline
\end{tabular}

The degree of swelling is highest at $50^{\circ} \mathrm{C}$ and over $60^{\circ} \mathrm{C}$ the peptization takes place. In the experiments mentioned above the time of immersion was $40 \mathrm{~min}$. Wc further estimated the volume of tuber particles in acid or alkali solutions.

Table 6. Swelling of tuber powder in various solutions.

\begin{tabular}{l|c|c|c|c|c}
\hline Temperature of immersion, ${ }^{\circ} \mathrm{C}$ & 20 & 30 & 40 & 50 & 60 \\
\hline Swelling in $1 \% \mathrm{HCl} \ldots \ldots \ldots \ldots$ & 210 & 230 & 270 & 215 & - \\
Swelling in $5 \% \mathrm{NaOH} \ldots \ldots \ldots$ & 225 & 270 & 300 & 280 & 250 \\
Swelling in $1 \% \mathrm{Na}_{2} \mathrm{NO}_{3} \ldots \ldots$. & 225 & 245 & 250 & 280 & 240 \\
\hline
\end{tabular}

As is shown in Table 6 , the greatest increase of tuber volume is brought about in sodium hydroxide solution. 
In general, it is somewhat difficult to prepare Lycoris starch of superior quality in good yield. For example, the glucose determination after acid hydrolysis gave the results represented in Table 7 .

Table 7. Purity of Lycoris starch preparation.

\begin{tabular}{c|ccccc}
\hline & Excellent quality & Bad quality \\
\hline Starch content, $\%$ & $\ldots$ & $\ldots \ldots \ldots \ldots$ & 90.0 & 73.4 \\
\hline
\end{tabular}

The preparations of inferior quality were made from the residue which remained after the isolation of those of good quality.

2. Action of amylase: There is no report on the enzymatic decomposition of Lycoris starch. In the present investigation we used two kinds of enzymes of different origins, viz. malt amylase and Taka diastase. Barley malts were manufactured in this laboratory and dried at $40^{\circ} \mathrm{C}$. The extract of malt powder or the suspension of Taka diastase was employed as amylase preparation. For instance, $1 \mathrm{cc}$ of such a enzyme solution was added to the mixture of $25 \mathrm{cc} 1 \%$ starch solution and $10 \mathrm{cc}$ phosphate buffer. In most experiments the time of reaction was $40 \mathrm{~min}$. and the temperature $55^{\circ} \mathrm{C}$.

Table 8. Action of amylase on Lycoris starch at various acidities.

\begin{tabular}{c|r|r|r|r|r|r|r|r|r}
\hline $\mathrm{pH}$ of solution & 4.5 & 4.8 & 5.4 & 5.6 & 5.9 & 6.3 & 6.9 & 7.2 & 7.7 \\
\hline Malt; mg glucose ..... & 118 & $\mathrm{l} 22$ & 132 & 140 & 136 & 127 & 116 & 89 & 46 \\
Taka; mg glucose..... & 124 & 132 & 135 & 130 & 123 & 121 & 106 & 102 & 82 \\
\hline
\end{tabular}

The data of Table 8 indicate that in alkaline medium the activity of amylase is relatively weak.

In the experiments in Table 9 the acidity of solutions was kept at $\mathrm{pH}$ 5.4. The results obtained show that the enzymatic hydrolysis of Lycoris starch occurs powerfully even at high temperature.

Table 9. Amylolytic decomposition of starch at different temperatures.

\begin{tabular}{c|c|c|c|c|c|c|cc}
\hline Temp. of reaction & 36 & 45 & 50 & 55 & 60 & 65 & 70 & 75 \\
\hline Mait; mg glucose ... & 48 & 62 & 66 & 72 & 78 & 79 & 46 & 41 \\
Taka; $m g$ glucose ... & 52 & 61 & 67 & 65 & 59 & 54 & 36 & 21 \\
\hline
\end{tabular}


From the data in Table 10 it appears that neutral salts have no influence upon the saccharification of Lycoris starch by malt and Taka amylase.

Table 10. Effect of salts upon enzymatic hydrolysis of starch.

\begin{tabular}{c|c|c|c|c|c}
\hline Kind of salt & $\mathrm{NaCl}$ & $\mathrm{NH}_{4} \mathrm{Cl}$ & $\left(\mathrm{NH}_{4}\right)_{2} \mathrm{SO}_{4}$ & $\mathrm{KNO}_{3}$ & $\mathrm{H}_{2} \mathrm{O}$ \\
\hline Malt; mg glucose $\ldots . .$. & 67 & 66 & 65 & 62 & 60 \\
Taka; mg glucose ...... & 63 & 61 & 58 & 55 & 57 \\
\hline
\end{tabular}

The determination of viscosity was carried out with an Ostwald's apparatus. The Lycoris starch is easily liquefied by malt amylase, as the figures in Table 11 indicate.

Table 11. Liquefaction of Lycoris starch at different hydrogen ion concentrations.

\begin{tabular}{l|c|c|c|c|c|c|c}
\hline Acidity of solution, pH & 5.0 & 5.4 & 5.6 & 5.9 & 6.2 & 6.4 & 6.6 \\
\hline Time of flow, sec. ...... & 182 & 179 & 177 & 174 & 176 & 178 & 180 \\
\hline
\end{tabular}

Table 12. Enzymatic liquefaction of starch at varius temperatures.

\begin{tabular}{l|l|l|r|r|r|r|r}
\hline Temp. of reaction, ${ }^{3} \mathrm{C}$. & 37 & 42 & 47 & 52 & 59 & 65 & 70 \\
\hline Time of flow, sec. ...... & 185 & 174 & 180 & 181 & 184 & 187 & 190 \\
\hline
\end{tabular}

As can be seen from Table 12, the optimum temperature for the liquefaction is $42^{\circ} \mathrm{C}$. In these experiments the time of reaction was always $20 \mathrm{~min}$.

\section{SUMMARY}

Experiments on the preparation of Lycoris starch were carried out under various conditions. It seems somewhat difficult that the starch of excellent quality is isolated from the bulbs in high yield.

Various experiments on the decomposition of Lycoris starch by amylase were also performed. It was found that the starch is easily decomposed by malt amylase as well as by Taka diastase.

We wish to express our thanks to Mr. T. Miyakuni and Mr. M. Watayama for their assistance. 


\section{REFERENCES}

1. H. Kondo et al.: Jl. pharm. Soc. Japan, 52, 433 (1932) 54, 997 (1934).

2) K. Yamafuji and H. Kondo: Jl. Agr. Chem. Soc. Japan, in press.

3) T. Akita and T. Nakashima: ibid., in press.

4) Y. Kihara: ibid., 9, 1005 (1933).

5) K. Yamafuji and T. Akita: ibici, in press. 